\title{
A parasitic myoma: clinicopathological study of a rare case
}

\author{
Nanda J. Patil, Puja A. Pingle*, Gayatri N. Patel
}

Department of Pathology, KIMS, Karad, Maharashtra, India

Received: 01 November 2017

Accepted: 25 November 2017

\section{*Correspondence:}

Dr. Puja A. Pingle,

E-mail: pooja.pingle1210@gmail.com

Copyright: (c) the author(s), publisher and licensee Medip Academy. This is an open-access article distributed under the terms of the Creative Commons Attribution Non-Commercial License, which permits unrestricted non-commercial use, distribution, and reproduction in any medium, provided the original work is properly cited.

\begin{abstract}
Leiomyoma is a benign tumour composed of smooth muscle cells with fibrous stroma and it is the commonest tumour amongst the tumours of uterus. As per FIGO classification system parasitic leiomyoma has no myometrial involvement or uterine attachment. These myomas get detached from the uterus and receive the blood supply from another source. The etiology and pathologic basis of these parasitic fibroids is not yet clearly understood. We report a rare case of parasitic myoma in a 29 years old female patient presented with abdominal discomfort and difficulty in micturition. Clinical examination and subsequent imaging studies revealed a pelvic mass. Histopathological examination of which proved it to be a parasitic myoma. Parasitic myoma is a rare entity which may be iatrogenically created after surgery particularly with morcellation technique. With increasing rates of laparoscopic procedures, surgeons should be aware of the possibility of formation of parasitic myoma and should take intraoperative precautions to minimise its formation.
\end{abstract}

Keywords: Leiomyoma, Parasitic, Pelvis

\section{INTRODUCTION}

Leiomyoma is a benign tumor composed of smooth muscle cells with fibrous stroma. It is the commonest tumor amongst the tumours of uterus. As per FIGO classification system parasitic leiomyoma has no myometrial involvement or uterine attachment. ${ }^{1}$

These leiomyomas become detached from uterus and receive blood supply from another source or other adjacent organs. The exact etiology and pathogenesis of parasitic myoma is not clearly known. ${ }^{2}$ It is thought that parasitic myoma is a rare type of pedunculated subserosal myoma which has a long stalk and hence gets detached from the uterus and survive by neovascularisation of adjacent tissues such as omentum and the mesenteric vessels. $^{3}$

The other names for parasitic myoma are wandering fibroid, migrating fibroid or ectopic fibroid. ${ }^{4}$ Another theory suggests that iatrogenic parasitic myomas result from seedling of remnants of fibroid during morcellation at the time of myomectomy or hysterectomy. ${ }^{5}$ Peritoneal metaplasia is another theory which describes the pathogenesis of myomas at unexpected sites. ${ }^{6}$

Recent studies have revealed 0.9-1.2\% incidence rate of parasitic myoma after laparoscopic myomectomy. The interval between surgery and diagnosis of parasitic myoma ranges from 2 to 192 months. $^{7}$

\section{CASE REPORT}

A 29 years old female patient presented with abdominal discomfort and difficulty in micturition since 5 to 6 weeks. She had history of previous LSCS 10 years back. There was no history of previous myomectomy. Per vaginal examination reveals fullness of urinary bladder with big mass pressing the pelvic wall anteriorly. USG abdomen revealed a large mass mimicking a myoma near 
the posterior wall of cervix with no attachment to uterus or cervix (Figure 1).

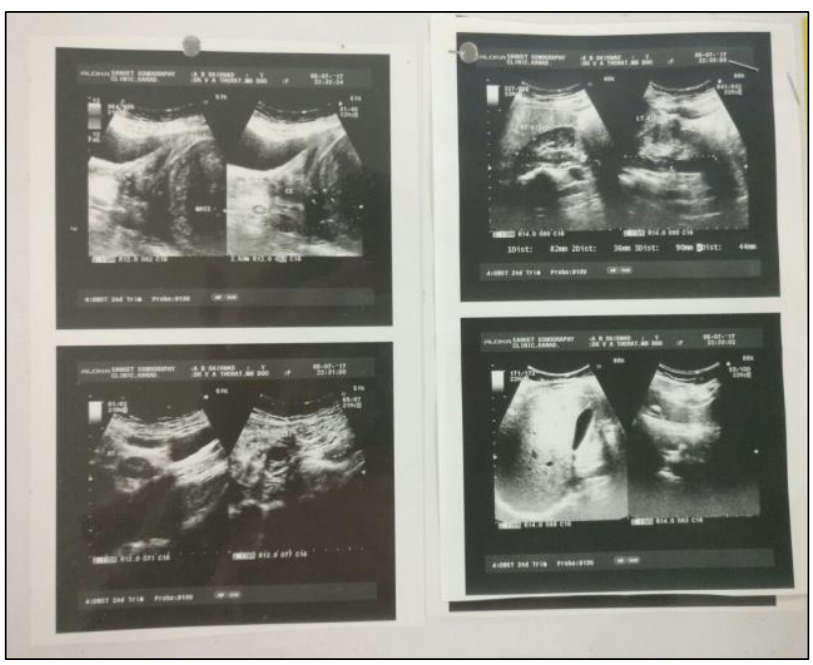

Figure 1: A large mass near the posterior wall of uterus with no attachment.

Intravenous urography revealed well defined round to oval hyperdense lesion in the pelvic cavity measuring 14 $\times 11 \times 09 \mathrm{~cm}$ (Figure 2).

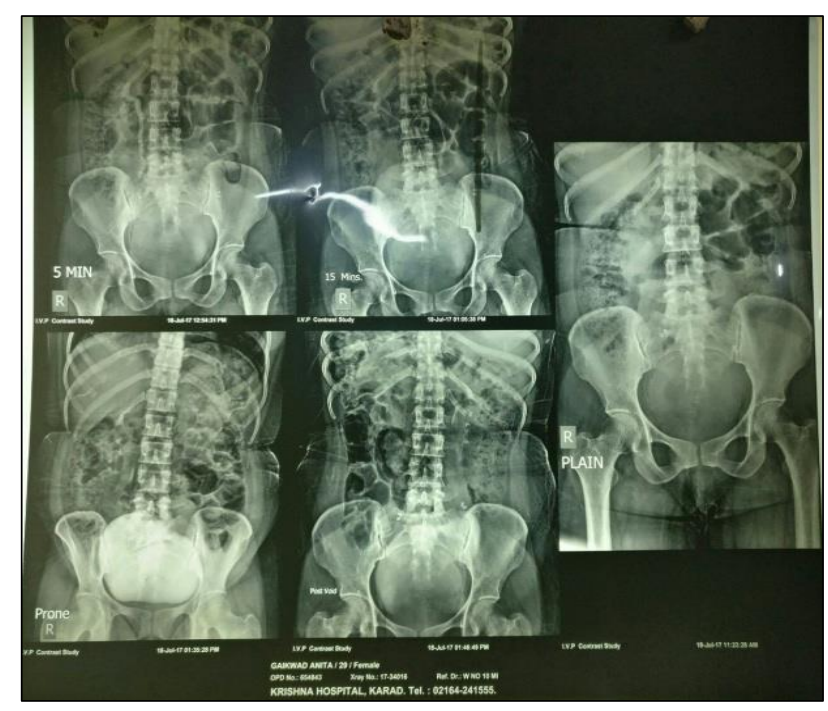

Figure 2: Intravenous urography-lesion in pelvic cavity $14 \times 11 \times 9 \mathrm{~cm}$.

The mass was removed along with uterus and cervix. Intraoperative findings revealed a large mass of size $14 \times$ $11 \times 09 \mathrm{~cm}$ in left ischiorectal fossa completely separate from the uterus.

\section{Histopathological examination}

Gross examination revealed a huge mass of size $13 \times 13$ $\times 7 \mathrm{~cm}$, weighing $1.2 \mathrm{~kg}$. Cut section of the mass revealed grey white solid areas with whorled pattern along with cystic degeneration (Figure 3 and 4).

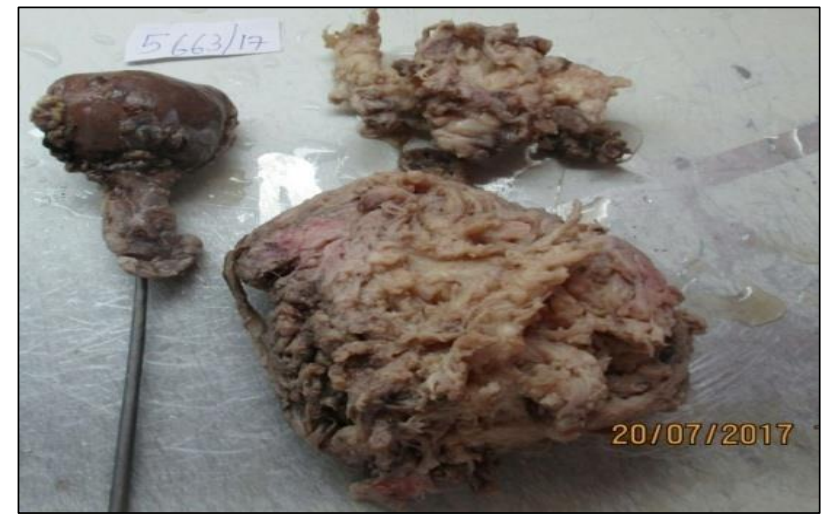

Figure 3: Grey white globular mass with separate uterus.

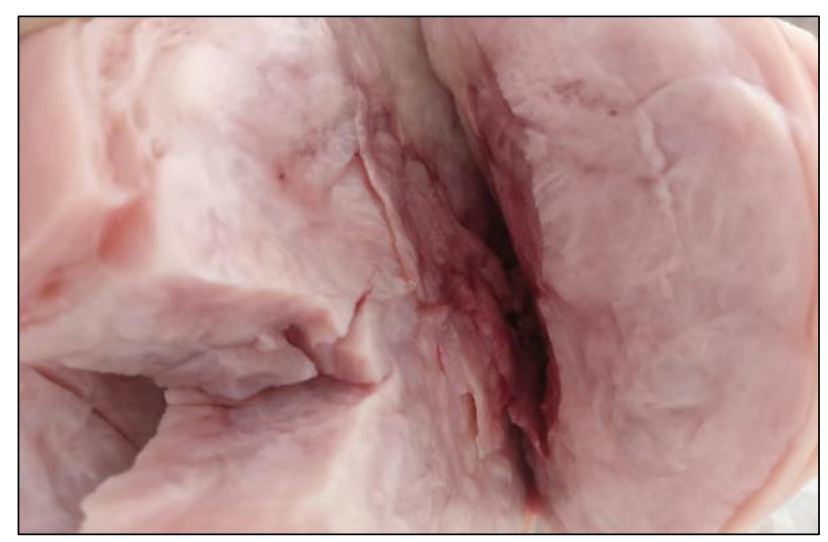

Figure 4: Cut section showed whorled appearance.

Microscopy revealed a tumour composed of interlacing bundles of smooth muscles without nuclear atypia and interlacing hyaline stroma (Figure 5).

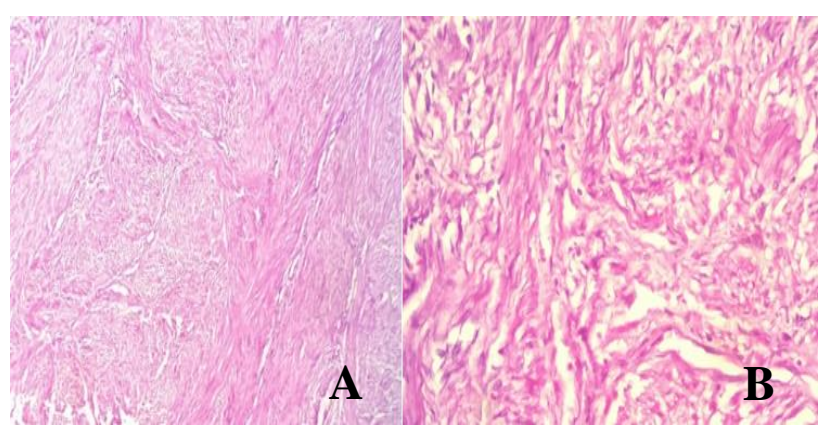

Figure 5: A tumor composed of smooth muscle cells with hyaline stroma (A-100x, B-400x, H\&E).

\section{DISCUSSION}

Our case presented with abdominal discomfort and a pelvic mass. There was no history of previous myomectomy. Possibility of iatrogenic leiomyoma is ruled out in this case. In our case the present tumour must be a pedunculated subserosal leiomyoma detached from the uterus. The sites of parasitic fibroid are pararectal fossa, abdominal wall, appendix, paravesical space, 
intestinal serosa, rectus muscle and bowel mesentry. ${ }^{8}$ In our case the presenting site of parasitic fibroid was ischiorectal fossa, pressing the bladder causing retention of the urine. The small myomas may remain asymptomatic while the larger masses cause pressure symptoms and abdominal discomfort as in our case. Differential diagnosis of parasitic myomas are ovarian tumours (primary or secondary), broad ligament cyst, lymphadenopathy and solid malignant pelvic tumour. Transvaginal ultrasonography may be useful in diagnosing parasitic myomas. ${ }^{9}$

\section{Treatment}

The myomas in the mesentry are attached firmly to the bowel wall and hence extensive surgery may be required during removal. Non-surgical treatment with $\mathrm{GnRH}$ is thought to be effective for small fibroids. ${ }^{10}$

\section{CONCLUSION}

Parasitic leiomyomas are rare tumours which may be iatrogenically created after surgery particularly with morcellation technique. With increasing rates of laparoscopic procedures surgeons should be aware of the possibility of formation of parasitic myomas and should take intra-operative precautions to minimize its formation. Proper precautions like repeated washing and aspiration should be taken during abdomino-pelvic surgeries. Parasitic myomas should be thus included in the differential diagnosis of abdominal masses in female patients.

\section{Funding: No funding sources}

Conflict of interest: None declared

Ethical approval: Not required

\section{REFERENCES}

1. Jones HW, Rock JA. Leiomyomata Uteri and Myomectomy. In: Jones HW, eds. Te Linde's
Operative Gynaecology. $11^{\text {th }}$ ed. Philadelphia, (PA): Wolters Kluwer; 2015:658-662.

2. Kelly HA, Cullen TS. Myomata of uterus. Philadelphia: W B Saunders; 1909:451.

3. Robbins SL, Cotran RS, Kumar V. Pathologic basis of disease. $3^{\text {rd }}$ ed. Philadelphia (PA): WB Saunders; 1984:1109.

4. Kale T, Tambe S, Alnur Y. Parasitic fibroid: a diagnostic dilemma. New Indian J Obstet Gynecol. 2016;3(1):47-50.

5. Kho KA, Nezhat, Ceana. Parasitic Myoma. Obstetric/Gynaecol. 2009;114:611-5.

6. Berek JS. Uterine fibroids. In: Berek JS, eds. Berek and Novak's Gynecology. 15 ${ }^{\text {th }}$ ed. Philadelphia, (PA): Lipincott William and Wilkins; 2013:444-445.

7. Cucinella G, Granese R, Calagna G, Somigliana E, Perino A. Parasitic myomas after laparoscopic surgery: an emerging complication in the use of morcellator. Description of four cases? Fertil Steril 2011;96:90-96.

8. Wada-Hiraike O, Yamamato N, Osuga Y, Yano T, Kozuma S, Taketani Y. Aberrant implantation and growth of uterine leiomyoma in the abdominal wall after laparoscopically assisted myomectomy. Fertil Steril. 2009;92:1747-e13.

9. Najila F, Alampady K, Prasad S, David M. Leiomyomas beyond the uterus: Unusual locations, rare manifestations. Radiographics. 2008;28:193148.

10. Kumar S, Sharma JB, Verma D, Gupta P, Roy KK, Malhotra N. Disseminated peritoneal leiomyomatosis: an unusual complication of laparoscopic myomectomy. Arch Gynecol Obstet. 2008;278:93-5.

Cite this article as: Patil NJ, Pingle PA, Patel GN. A parasitic myoma: clinicopathological study of a rare case. Int J Reprod Contracept Obstet Gynecol 2018;7:352-4. 